\title{
Meteorological environment of a tornado outbreak in Southern Romania
}

\author{
I. C. Oprea and A. Bell \\ National Meteorological Administration, 97, Bucuresti-Ploiesti, Bucharest, Romania \\ Received: 4 November 2008 - Revised: 14 April 2009 - Accepted: 14 April 2009 - Published: 23 April 2009
}

\begin{abstract}
On 7 May 2005, a squall line with an embedded bow echo formed over Southern Romania causing severe wind damage. The length of the wind damage was around $150 \mathrm{~km}$. Three tornadoes have been reported, two of them being recorded by video camera. One of the tornadoes occurred in Buftea (near Bucharest), the second in Ciobanu village (near Medgidia radar site) and the third in Movilita village, $40 \mathrm{~km}$ to the northeast of Bucharest. The site surveys confirmed wind damage associated with these tornadoes. Based on damage, the Movilita village tornado was classified as an F1 type on the Fujita scale, and the Buftea and Ciobanu village tornadoes were classified as F0. Large scale forcing was provided by a vigorous upper level trough. The squall line developed in the warm sector of a low, ahead of the cold front. The Bucharest EEC-DWSR-2500C Doppler velocity depicted cyclonically rotational structures associated with the left end of the bow echo. In two hours this squall line traversed the southern part of the country. The northern end of the line preserved the bowed structures and high reflectivity gradient in front of them. The dry air associated with the descending rear inflow jet was evident as rear inflow notches in the reflectivity field of the Bucharest C-band radar and the Medgidia S-band WSR-98 D radar. The synoptic and mesoscale environment associated with 7 May 2005 bow echo had many similarities to the "dynamic" pattern described by John and Hirt (1987). Herein are analyzed the combined effects of synoptic and mesoscale circulations, together with the data provided by C-band EEC-DWSR-2500C and S-band WSR-98D radars, and the ECMWF and ALADIN model output data. Some operational aspects of the warning process are also discussed.
\end{abstract}

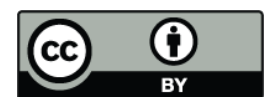

Correspondence to: A. Bell (aurora.bell@meteoromania.ro)

\section{Introduction}

Bow echoes are a unique form of convective organization that often produces severe weather, especially damaging straightline winds and tornadoes. Fujita (1978) realized the first well-known conceptual model with his schematic (Fig. 1a) that shows how an initial straight echo transforms into a bow-shaped line of convective cells with the strongest winds occurring at the apex of the bow. During its most intense phase (Fig. 1a, C), the center of the bow may form a spearhead echo (Fujita and Byers, 1977). During the declining stage, the system often evolves into a comma-shaped echo with cyclonic and anticyclonic rotation at the end of the bow (Fig. 1a, D). Fujita's first observational studies confirmed the existence of tornadic damage generally collocated with the apex of the bow (Fujita, 1978, 1981). Subsequent observational studies documented tornadoes occurring with the apex of the bow (Forbes and Wakimoto, 1983; Wakimoto, 1983; Przybylinski, 1995; Funk et al., 1999; Atkins et al., 2004) or associated with the cyclonically rotating "comma head echo" (Weisman, 1993; Pfost and Gerard, 1997). The studies about the mesovortices associated with the apex of the bow or the bookend vortices (Weisman, 1990) associated with the northern end bow echo were progressed upon the installation of WSR-88D radar in the early 1990s, when the Doppler winds offered the opportunity to identify cyclonic and anticyclonic rotational features (Burgess and Smull, 1990; Weisman, 1993; Jorgensen and Smull, 1993; Przybylinski et al., 2000; Arnett and Atkins, 2002; Atkins et al., 2004).

Convectively generated windstorms occur over a wide array of temporal and spatial scales (Fujita, 1978; Fujita and Wakimoto, 1981); however, the more widespread and longer lived of these windstorms are termed "derechos" (Hinrichs, 1888; Johns and Hirt, 1987). By analyzing the radar summary charts associated with 70 warm-season cases of convectively induced straight-line windstorm, Johns and Hirt (1987) identified two basic echo patterns. The first pattern,

Published by Copernicus Publications on behalf of the European Geosciences Union. 


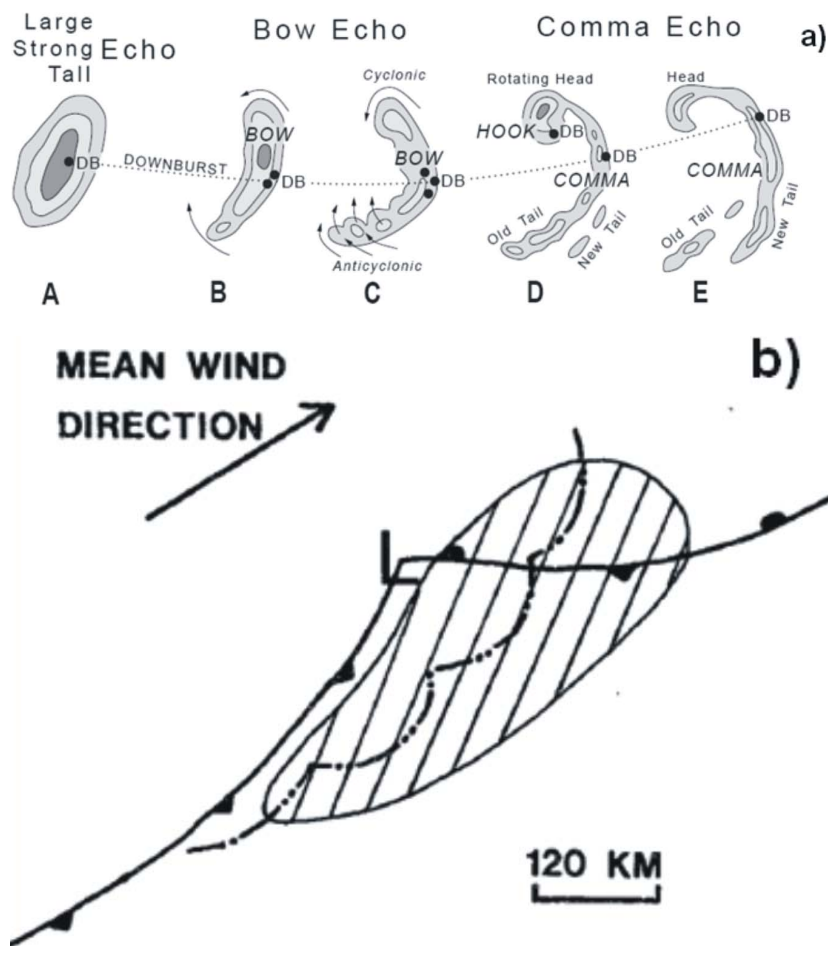

Fig. 1. (a) Fujita's (1978) conceptual model of a bow echo with a rotating comma head. (b) Schematic representation of features associated with a "dynamic" synoptic pattern. Total area affected by widespread wind damage indicated by hatching. Frontal and squall line symbols are conventional (Johns and Hirt, 1987).

termed "progressive", consists of a single bowed segment that moves parallel to a quasi-stationary front. The second pattern, named "serial", consists of a series of bows that propagate along a large-scale squall line. The "progressive" derechoes are mostly associated with the warm-season atmospheric conditions, when amounts of convective instability and low level moisture are very high (Johns, 1993). The bow-echoes move along a quasi-stationary low-level thermal boundary orientated nearly parallel to the mean flow that is often westerly to north-westerly (John and Hirt, 1987). The "serial" derecho was associated by Johns (1993) with a "dynamic" pattern (Fig. 1b) that consists of a strong, migrating low pressure system associated in general with severe weather systems (Johns and Doswell, 1992).

Evans and Doswell (2001) extend the work on derecho producing convective storm environments by examining proximity soundings from 67 derechoes cases from all times of the year. The authors observed that derechoes occur under a wide range of atmospheric conditions, and included an additional pattern, named "hybrids" derechoes, that display features of both the warm-season and dynamic patterns. Conoglio et al. (2004) documented the spectrum of large scale environment flow patterns from a set of 225 analyses of 500-hPa geopotential heights associated with

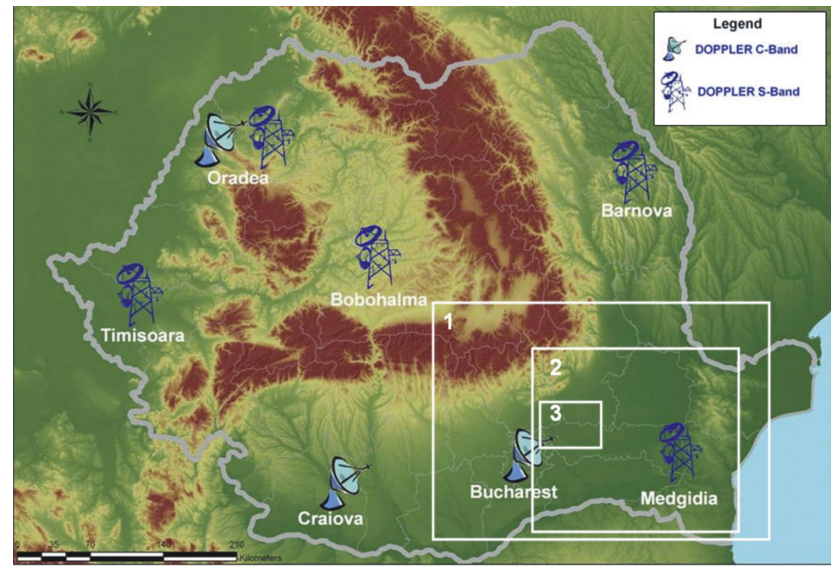

Fig. 2. The Romanian National Radar Network integrates: five WSR-98 D S-band, two EEC-DWSR-2500 C-band and one Gematronik-METEOR $500 \mathrm{C}$-band. The white rectangle number 1 represents the extent of the region in Fig. 3. The rectangles number 2 and 3 represent the area in radar images that will be used later in the text.

the development and early evolution of derecho producing convective systems. The majority of the events (72\%) fell into three main patterns that include a well-defined upstream trough $(40 \%)$, a ridge $(20 \%)$, and a zonal, low-amplitude flow $(12 \%)$. The remaining $28 \%$ of the cases form largescale hybrid patterns that contain various characteristics of the three main patterns. In addition Conoglio et al. (2004) found that low level shear (instability) is significantly higher (lower) for the more strongly forced events, while the low level storm-relative inflow tends to be much deeper for the more weakly forced events.

Almost all the derecho producing convective storms studies in the last decades refer to cases that have affected the United States. Although it is likely that derecho producing convective storms occur in other parts of the world, only few cases have been described in the literature. A severe bowecho storm passed over Northern Switzerland and Southern Germany on 22 July 1995 and wind damage was reported in both countries (Schmid et al., 2000). On 5 July 2002 a rapidly propagating bow echo formed over Eastern Finland causing severe wind damage in an exceptionally large area (Punkka et al., 2006), and on 10 July 2002, a bow echo producing a derecho affected the capital of Germany (Gatzen, 2004). In August 2003 a mesoscale convective storm caused severe wind damage in Northeastern Spain and Southern France (López and Arús, 2004).

On 7 May 2005, a squall line with an embedded bow echo formed over Southern Romania causing severe wind damage. Three tornadoes have been reported, two of them being recorded by video camera. The site survey confirmed wind damage associated with these tornadoes, two of them were $\mathrm{F} 0$ and the third was more intense being classified as F1 on the Fujita scale. 
A major responsibility of the Romanian National Weather Forecast Centre is to issue warnings of severe weather (severe thunderstorms, flash flood, tornadoes). The Romanian National Weather Service began the operational use of the five WSR-98 D (Weather Surveillance Radar-1998D) in 2002 that together with two EEC-DWSR-2500C Doppler radars and one Gematronik-METEOR 500C type installed in 2001 form nationwide coverage radar Doppler network (Fig. 2). This radar network system contains numerous algorithms that use Doppler radar base data - reflectivity (dBZ) and velocity $\left(\mathrm{m} \mathrm{s}^{-1}\right)$ - as input to produce meteorological analyses. Romanian forecasters have required time to adjust their interpretation of radar algorithm output and severe weather warning thresholds. Based on past experience in analog radar observations (since the 1970s) three thresholds with different intensity intervals for severe weather, warnings have been introduced. These thresholds include weak, moderate and high intensities for convective events. Forecasting and monitoring potentially severe thunderstorms with high intensities for wind speed, high rainfall rate and hail in the context of the variety of Romanian relief constitutes a significant challenge, because in most cases, various kinds of severe weather occur simultaneously. This was the situation on 7 May 2005, in Southern Romania, when tornadoes, high winds and hail affected the plain region from the south of the country, and torrential rain in the hilly part that produced, in the interval immediately following, a major flash flood. This case is not only interesting meteorologically, but also because it shows how the simultaneous occurrence of severe whether events can decrease the efficiency of the operational weather short term forecasting system.

The environment in Southern Romania tends to be more conducive to severe convection than in other parts of the country (Stan-Sion and Antonescu, 2006). Interactions of the synoptic flows with the curved shape of the Carpathian Mountains results in convergence zones in this part of the country (Bell, 2008). If necessary ingredients (lift, instability and moisture) exist (Doswell et al., 1996), then severe convection is initiated near this convergence zone (Stan-Sion et al., 2006, 2007). The first tornado observed in Southern Romania using Doppler radar was at Facaeni (Lemon et al., 2003), after which the tornado threat in Romania became recognized. That this storm formed in Romania from a supercell meant that supercell storms become "targets" for nowcasting severe weather. Romanian forecasters were challenged to recognize environmental factors that favor supercell development, while the environment that is particularly favorable for bow echo formation had not been reviewed at the time of this event. Further, tornadoes associated with bow echoes were a concept totally unknown to our forecasters.

Early on 7 May 2005, the convective event began as an elongated area of thunderstorms over hilly region in Southern Romania between 06:00 UTC and 09:00, while a small cluster of convective cells passed from Bulgaria into Southern Romania and moved north-east. The convective system
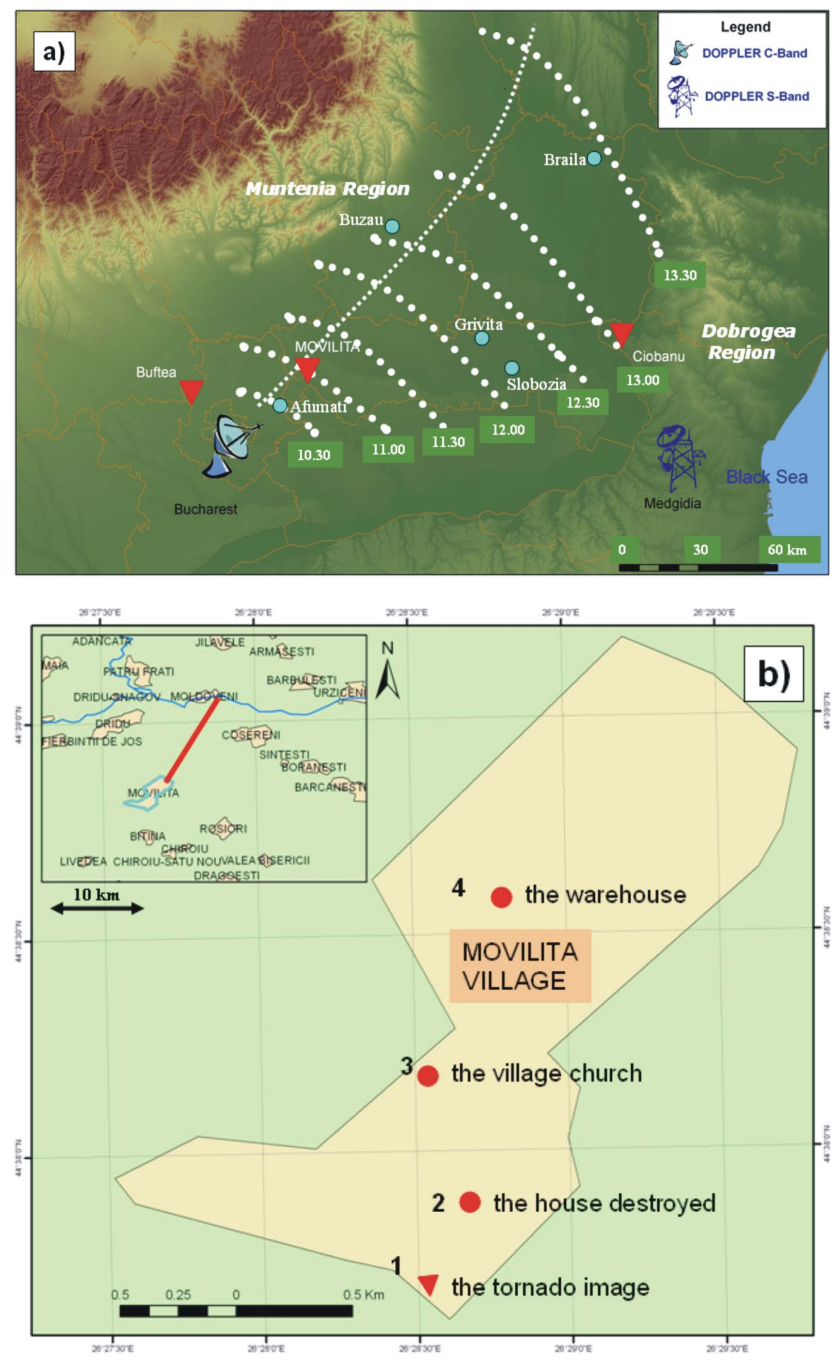

Fig. 3. The location and wind damage reports of the 7 May 2008 event area. (a) The geography of the south-eastern part of Romania and radar locations are indicated. The area depicted is a zoom represented by the white rectangle number 1 from Fig. 2. The squall line locations every half hour between 10:30 UTC and 13:30 UTC are depicted with round dot lines. With red triangles are indicated the tornado reports from Buftea, Movilita and Ciobanu villages and with blue circles are indicated the $10 \mathrm{~m}$ wind gust reports greater than $16 \mathrm{~m} \mathrm{~s}^{-1}$. The length of the damage is around $150 \mathrm{~km}$. (b) The location of the wind damage report in Movilita village and area around this village. The red line from the left corner shows the direction of the scattered narrow damage path area observed northeast for about $10 \mathrm{~km}$ toward Moldoveni village.

evolved into a squall line with bow echo near Bucharest, and brought damaging wind and three small tornadoes, two of which were recorded by video camera. One of the tornadoes occurred in Buftea (near Bucharest), the second in Ciobanu village (56 $\mathrm{km}$ from the Medgidia radar site) and the third in Movilita village, $40 \mathrm{~km}$ from Bucharest, in the north-east direction (Fig. 3), which caused the greatest wind damage. 

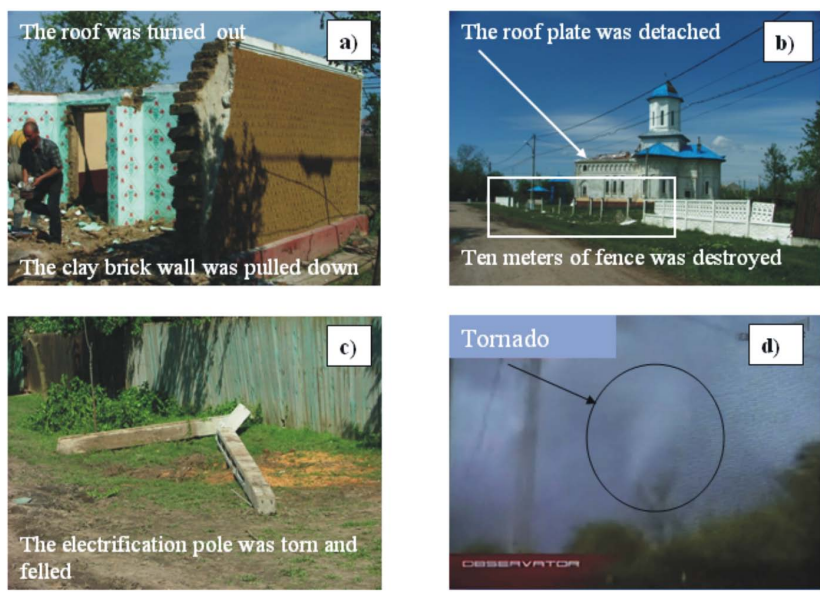

Fig. 4. Damage survey in Movilita village.

Our goals in this study are, firstly, to identify characteristics of the synoptic and mesoscale environment that were favorable for producing and sustaining the squall line with bow echo in 7 May 2005 and, secondly, to find mesoscale and convective scale factors that determine the evolution and location of the convective event. Analysis of weather phenomenon associated with deep moist convection is made through the evaluation of basic ingredients and their possible contribution and interactions (Doswell, 1996). Thus, deep moist convection is initiated if latent instability, moisture and sufficient lift are present. Synoptic scale and mesoscale processes are evaluated using numerical model outputs from ECMWF (The European Centre for Medium Range Weather Forecasters, http://www.ecmwf. int/research/ifs/) and ALADIN (Aire Limitee Adaptation Dynamique Developpement InterNational, http://www.cnrm. meteo.fr/aladin/) data, Doppler radar products, conventional weather station data, Meteosat Second Generation (MSG-2) visible, and water vapor images. Further, we will compare synoptic and mesoscale features associated with the formation and evolution of the 7 May 2005 bow echo with conditions that favor bow echo development in USA observed by Johns and Hirt (Johns and Hirt, 1987; Jonhs, 1993).

\section{Damage survey analysis}

The squall line location every half hours between 10:30 UTC and 13:30 UTC and wind damage reports are depicted in Fig. 3a. The Movilita village damage (Fig. 3a) was reported around 11:00 UTC and was associated with the northern end bow echo. Buftea and Ciobanu village tornadoes (Fig. 3a) were associated with gust front mesovortices. In Afumati, Buzau, Grivita, Slobozia and Braila towns the $10 \mathrm{~m}$ wind gust reports were greater than $16 \mathrm{~m} \mathrm{~s}^{-1}$ (Fig. 3a). The horizontal length of the damage was around $150 \mathrm{~km}$.
An in situ damage survey in Movilita village was carried out, two days after the event by an expert team of the National Meteorological Administration formed by Cornel Soci, Bogdan Antonescu si Ruxandra Banica, and an internal report has been elaborated. The damage track began south of the Movilita village (red triangle marked with number 1 in Fig. 3b), extended about $0.5 \mathrm{~km}$ north-east (red circle marked with number 2 in Fig. 3b), then deviated toward the north-west (red circle marked with number 3 in Fig. 3b), and finally, the tornado tracked north-east for about $1 \mathrm{~km}$ (red circle marked with number 4 in Fig. 3b). A more narrow damage path was observed north-east for about $10 \mathrm{~km}$, toward Moldoveni village (Fig. 3b), where a path of about $10 \mathrm{~m}$ in a corn field was flattened. In Movilita village the roofs of 24 houses were damaged or torn out and a house clay brick wall was completely demolished (Fig. 4a). The village church had half of its roof plate fully detached, while the other half was intact. A ten meters length from the fence surrounding the church was destroyed (Fig. 4b). Some trees were torn, others uprooted, while some electrification poles were torn and felled (Fig. 4c), and pieces of iron plate hang in the trees.

The eye witness report mentioned that "... a howl rushed at us. The storm took the house roof, turned out in the air and drove it away far from the house. The wind broke the windows and the doors. Pieces from the wall spread around and five trees were uprooted. At the gate, one electrification pole was torn and felled. All this lasted a few minutes."

Other eye witness report mentioned that "The tornado went out from the corn field as a funnel. The whirl took the roof plate from the church and throws him a few tens of meters away. From the church, the stream wind went to the road as a snake. He took the big doors from the warehouse and raised them ten meters in the air. Before the tornado, small hail, like wheat seed dimensions fell down, lasting about ten minutes."

The image shot by an amateur during the storm is an unquestionable proof and was afterwards shown on television. In that image could be seen the rotational cloud structure, the whirl moving down to the Earth, but it is not clear whether or not it touched the ground surface (Fig. 4d). Based on the ground effects, this tornado can be classified as F1 type on the Fujita scale. A weaker tornado (F0) was recorded by an amateur near Buftea village (10 km north of Bucharest) in an unpopulated area (Fig. 3a). This tornado uprooted some trees and damaged a corn field. The witness mentioned that in Ciobanu village the wind damaged the roofs from two houses and uprooted some trees.

\section{Analysis of the meteorological environment of the tornado outbreak}

Synoptic scale and mesoscale processes are evaluated using numerical model fields from ECMWF and ALADIN numerical models, Doppler radar products, high resolution visible 
satellite imagery and conventional weather station data. Surface data from the meteorological stations from Romanian National Meteorological Administration were used for surface analyses. The surface data consisted of hourly observations of $2 \mathrm{~m}$ temperature, $2 \mathrm{~m}$ dewpoint, mean sea level pressure, $10 \mathrm{~m}$ wind speed and direction.

\subsection{Analysis of synoptic scale conditions}

The synoptic pattern at 00:00 UTC 7 May was dominated by a large, upper-level long wave trough over the Balkan Peninsula and a ridge axis over the Romania and Black Sea (Fig. 5a). It contained a low at 548 gpdam centered over the Ionic Sea with a trailing thermal trough implying cold advection. Two weak shortwave troughs (labeled SW1 and SW2 in Fig. 5a) were propagating through the long wave trough, and associated with small-scale cold advection in the south-eastern part of the low at the 500-hPa. Between 00:00 UTC and 06:00 UTC, this strong disturbance was advancing rapidly toward the north-east, and showed a negatively tilting of the trough. The shortwave troughs rotated cyclonically with the axis of the second shortwave trough entering Southern Romania (Fig. 5b). The position of the large upper level long wave trough changed considerably overnight (00:00-12:00 UTC 7 May). Thus at 12:00 UTC the negatively tilted axis of a trough was located over central part of Romania, with eastern part of the country placed in the southerly flow in an area of maximum diffluence (Fig. 5c). All this time Eastern Romania remained under the influence of a marked ridge in geopotential and thermal fields (Fig. 5). In this context, a large scale source of upward vertical motion was present.

At low levels, eleven hours before the event (at 00:00 UTC 7 May 2005), the Azores High ridge extended over the North Atlantic (1025 hPa at centre), a large low-pressure area was located over the North-European countries due to an intense activity of the Icelandic cyclone, and a Mediterranean cyclone was centered over Greece (Fig. 6a). During the previous day and the night, the Azores High pressure system was funneling cold air southward into the circulation of the Mediterranean low, contributing to the cyclone genesis and development. The Mediterranean cyclone-related warm front affected Western and South-Western Romania during the night. Between 00:00 UTC and 06:00 UTC, the surface low was moving rapidly to north-northeast. Thus at 06:00 UTC the centre of the low was over Bulgaria (Fig. 6b). As the day progressed, the low has intensified and moved, so that at 12:00 UTC, the centre of the low with $995 \mathrm{hPa}$ was situated over the southern part of Romania (Fig. 6c). This low advected southerly into southeasterly moist and warm air into the south of the country.
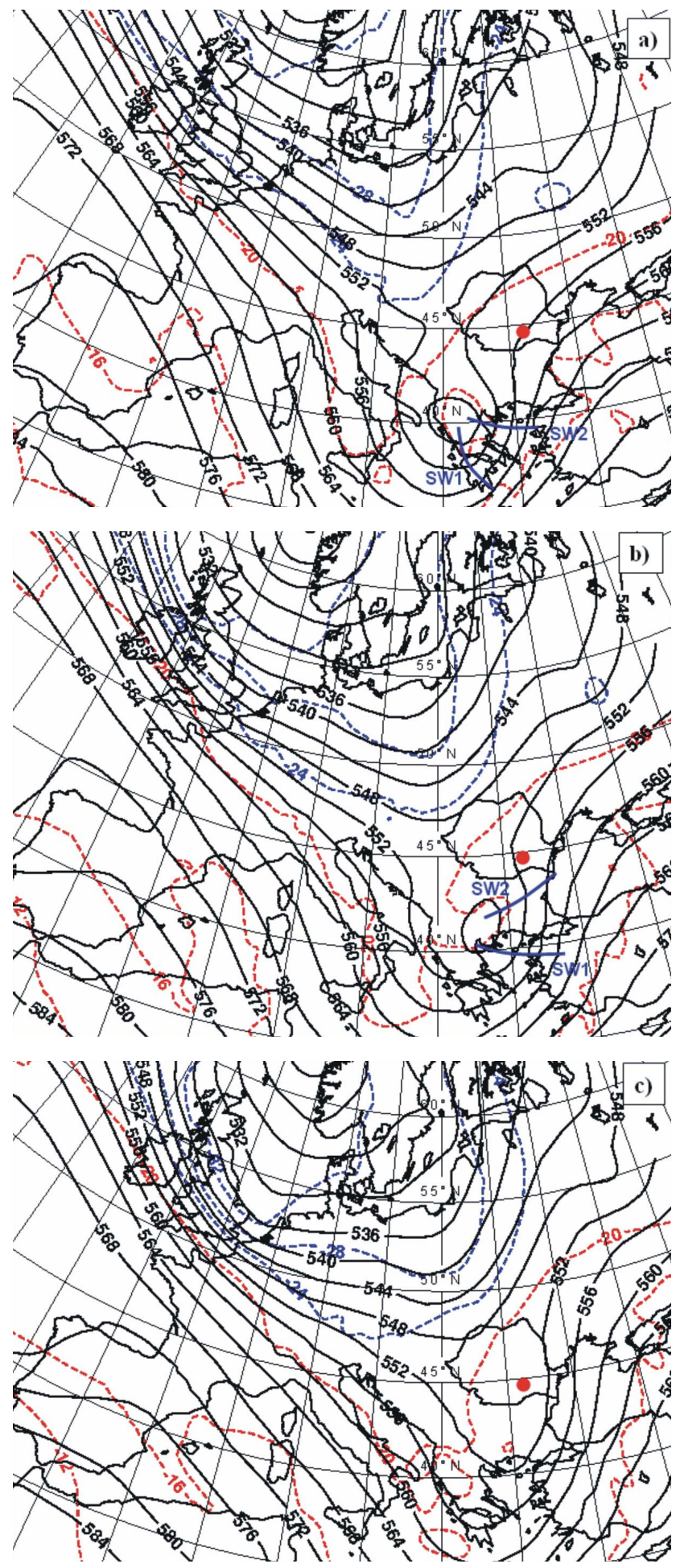

Fig. 5. The 500-hPa ECMWF model analysis of geopotential (thick black lines at 4 gpdam interval) and temperature (dashed blue and red lines at $4^{\circ} \mathrm{C}$ interval) at: (a) 00:00 UTC, (b) 06:00 UTC and (c) 12:00 UTC 7 May 2005. The event location in marked with a red circle. The short-wave troughs axes locations are marked with blue lines. 

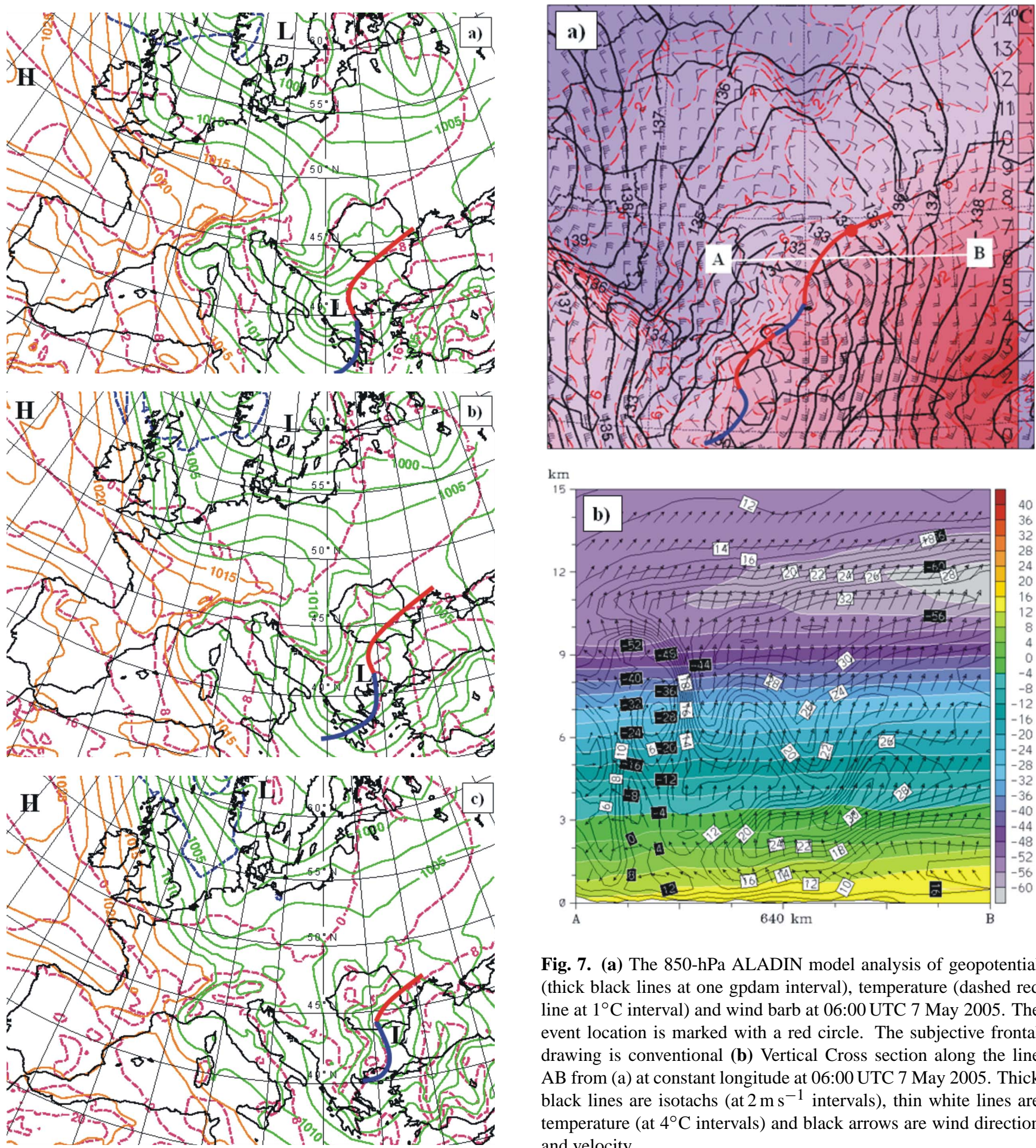

Fig. 7. (a) The $850-\mathrm{hPa}$ ALADIN model analysis of geopotential (thick black lines at one gpdam interval), temperature (dashed red line at $1^{\circ} \mathrm{C}$ interval) and wind barb at 06:00 UTC 7 May 2005. The event location is marked with a red circle. The subjective frontal drawing is conventional (b) Vertical Cross section along the line AB from (a) at constant longitude at 06:00 UTC 7 May 2005. Thick black lines are isotachs (at $2 \mathrm{~m} \mathrm{~s}^{-1}$ intervals), thin white lines are temperature (at $4^{\circ} \mathrm{C}$ intervals) and black arrows are wind direction and velocity.

Fig. 6. The low level ECMWF model analysis of mean sea level pressure (solid green and orange lines at $5 \mathrm{hPa}$ intervals) and 850-hPa temperature (dashed red lines at $4^{\circ} \mathrm{C}$ intervals) at: (a) 00:00 UTC, (b) 06:00 UTC and (c) 12:00 UTC 7 May 2005. The Azores High is depicted with " $\mathrm{H}$ " and Icelandic and Mediterranean Lows are depicted with "L". The solid red and blue lines are, respectively, warm and cold fronts associated with the Mediterranean Low.

\subsection{Analysis of mesoscale conditions}

Pronounced warm advection was observed at 850 -hPa over the south-east of the country and the Black Sea, where a ridge was visible in the thermal field from the ALADIN model at 06:00 UTC 7 May 2005, having the $9^{\circ} \mathrm{C}$ isotherm at 
the south of Romania associated with strong south-easterly winds $\left(16 \mathrm{~m} \mathrm{~s}^{-1}\right)$ (Fig. 7a). A vertical cross-section along the line AB in Fig. 7a at 06:00 UTC shows high velocity wind over the whole troposphere, with $14 \mathrm{~m} \mathrm{~s}^{-1}$ at $1000 \mathrm{~m}$ (Fig. 7b). Also, the wind direction was south-easterly at low-level and then turned within the first $2000 \mathrm{~m}$ and became southerly and nearly unidirectional above (Fig. 7b).

The strong moist and warm advection from south-east was identified also at 12:00 UTC as a tongue shape following the wet-bulb equivalent potential temperature contours at $925 \mathrm{hPa}$ level (Fig. 8a). Also, the 994-hPa low was centered over the south of the country and a strong gradient in the wet-bulb equivalent potential temperature contours and wind flows associated with the warm and cold front along Southern Romania could be observed (Fig. 8a). A vertical cross section along the line AB in Fig. 8a at 12:00 UTC was made through the centre of the surface low. The location of the squall line at 12:00 UTC relative to line AB is depicted with a black cross in Fig. 8b. One relative maxima of the wind is located at $1500 \mathrm{~m}$ to the rear of the squall line with values of $16 \mathrm{~m} \mathrm{~s}^{-1}$ and a south-south-west orientation (Fig. 8b). The vertical cross section of the wind shows the presence of a Low Level Jet at about $1500 \mathrm{~m}$ that is a common feature of cold fronts (Browning and Pardoe, 1973; Kotroni and Lagouvardos, 1993). Behind the relative squall line, at a distance about $200 \mathrm{~km}$, the vertical cross-section showed the presence of areas with high gradients in wind velocity and direction and with potential temperature discontinuities associated with the approaching cold front.

The vertical cross section depicts also the existence of a strong wind velocity gradient with one relative maxim of the wind down to $4000 \mathrm{~m}$ and reaching $30 \mathrm{~m} \mathrm{~s}^{-1}$, at 06:00 UTC (Fig. 7b) and $26 \mathrm{~m} \mathrm{~s}^{-1}$ at 12:00 UTC (Fig. 8b).

The spatial distribution of CAPE (Convective Available Potential Energy), according to ALADIN model data, at 12:00 UTC, shows that the greatest values appear over the south of Romania, where CAPE was around $2500 \mathrm{~J} \mathrm{Kg}^{-1}$ (Fig. 9). The ALADIN model uses the most unstable parcel of air found within the lowest $300 \mathrm{hPa}$ of the atmosphere to calculate CAPE, that is called MUCAPE (Most Unstable Convective Available Potential Energy). The analysis of the real vertical profile of the atmosphere could not be made because the squall line development did not allow the vertical sounding at Bucharest.

The subjective analysis of standard surface observations at 11:00 UTC depicted two thermal boundaries situated in the warm sector of the surface low. An area with high surface temperature gradients and surface wind convergence was analyzed in the North-East Muntenia region (Fig. 10). Another area with high surface temperature gradients and surface wet bulb temperature was located in Southeast Muntenia, in front of the approaching cold front. The surface temperature gradient was enhanced by diurnal heating $\left(22^{\circ} \mathrm{C}\right.$ at 11:00 UTC in the south-east of the country). The different orientation of the $10 \mathrm{~m}$ wind associated with these ther-

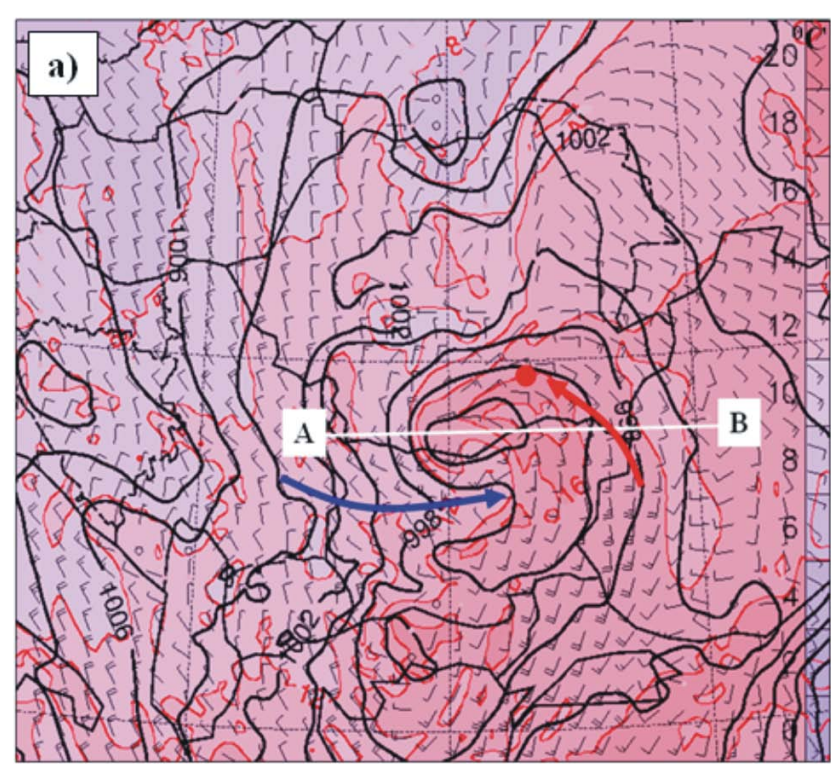

$\mathrm{km}$

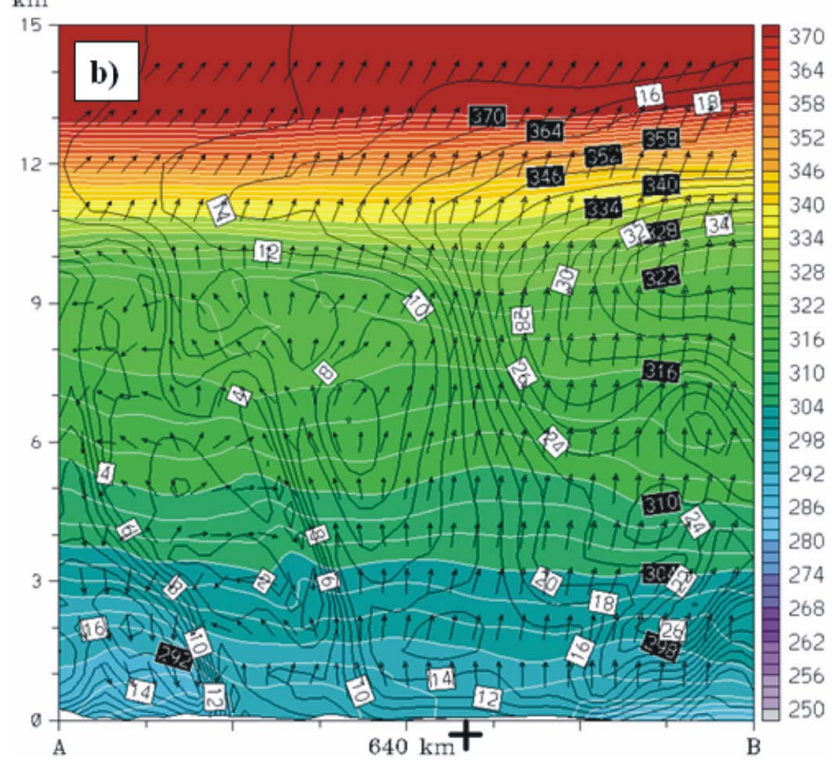

Fig. 8. (a) The mean sea level pressure (thick black lines at $2 \mathrm{hPa}$ intervals), wind at $10 \mathrm{~m}$ (with arrows) and wet bulb potential temperature at $925 \mathrm{hPa}$ (dashed red lines at $2^{\circ} \mathrm{C}$ intervals) from ALADIN model at 12:00 UTC 7 May 2005. The event location in marked with a red circle. The arrows indicate the warm and cold flows associated with the surface low. (b) Vertical cross-section along the line $\mathrm{AB}$ from (b) at constant longitude at 12:00 UTC. Thick black lines are isotachs (at $2 \mathrm{~m} \mathrm{~s}^{-1}$ intervals), thin white lines are potential temperature (at $6 \mathrm{~K}$ intervals) and black arrows are wind direction and velocity. The relative location of the squall line is depicted with a black cross.

mal boundaries is shown in Fig. 10. Convection became linearly organized by 09:00 UTC along the thermal boundary ahead of the cold front and showed bow echo features starting from 10:30 UTC. The bow echo propagated along the thermal boundary in the north-eastern part of Muntenia (Fig. 10). 


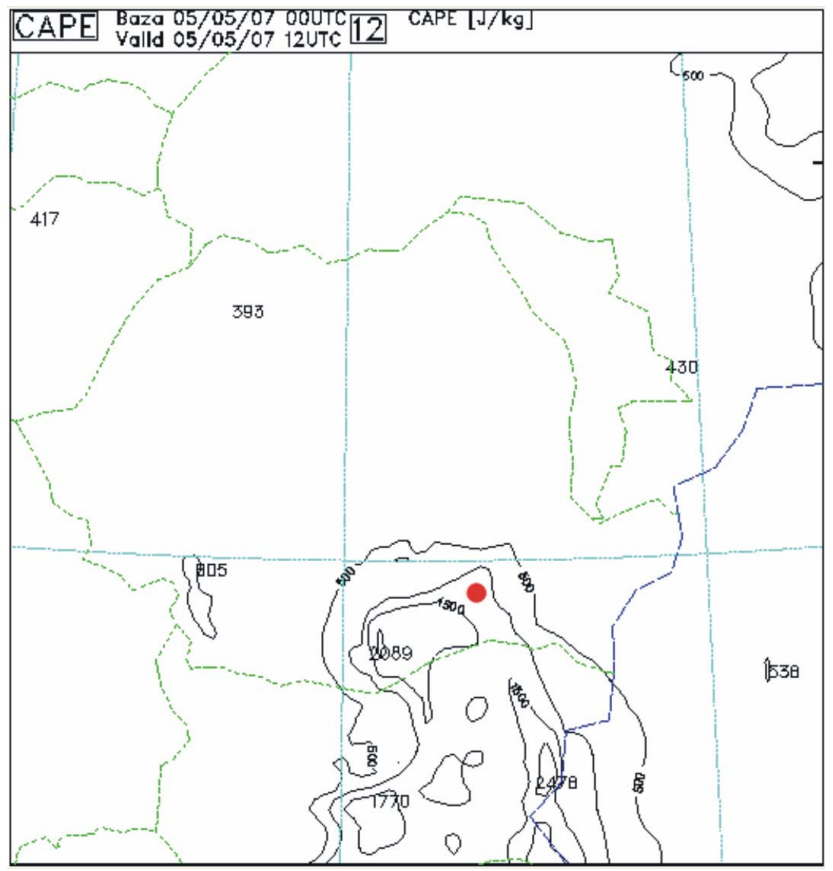

Fig. 9. Spatial distribution of CAPE (Convective Available Potential Energy) at 12:00 UTC 7 May 2005 from ALADIN model. The event location in marked with a red circle.

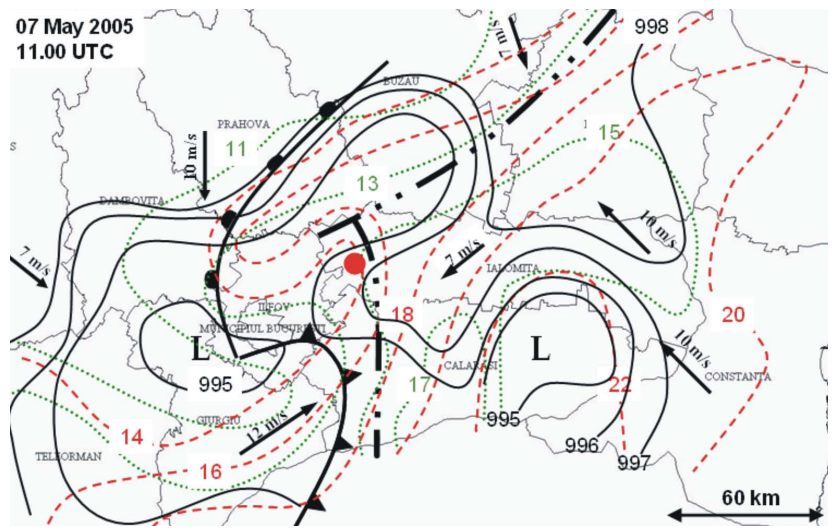

Fig. 10. The subjective analysis of standard surface observations for 11:00 UTC 7 May 2005. Identified are isobars (solid lines every $1 \mathrm{hPa}$ ), surface front (conventional symbol), position of the surface low (depicted by L), $2 \mathrm{~m}$ temperature (red dashed lines every $2^{\circ} \mathrm{C}$ ), $2 \mathrm{~m}$ dewpoint temperature in degrees Celsius (green dotted lines every $2^{\circ} \mathrm{C}$ ), and $10 \mathrm{~m}$ wind observations (black arrows). The thermal and moist convergence lines are depicted with long dashed-dot lines. The event location in marked with a red circle.

The existing high trough provided the rising energy for developing the early convection of that day, while the cold low of $-20^{\circ} \mathrm{C}$ at $500-\mathrm{hPa}$ (Fig. 5) located over the thermal ridge intensified the air column instability. The low-level warm and moist advection associated with thermal boundary provided mesoscale mechanisms necessary for convective initi-
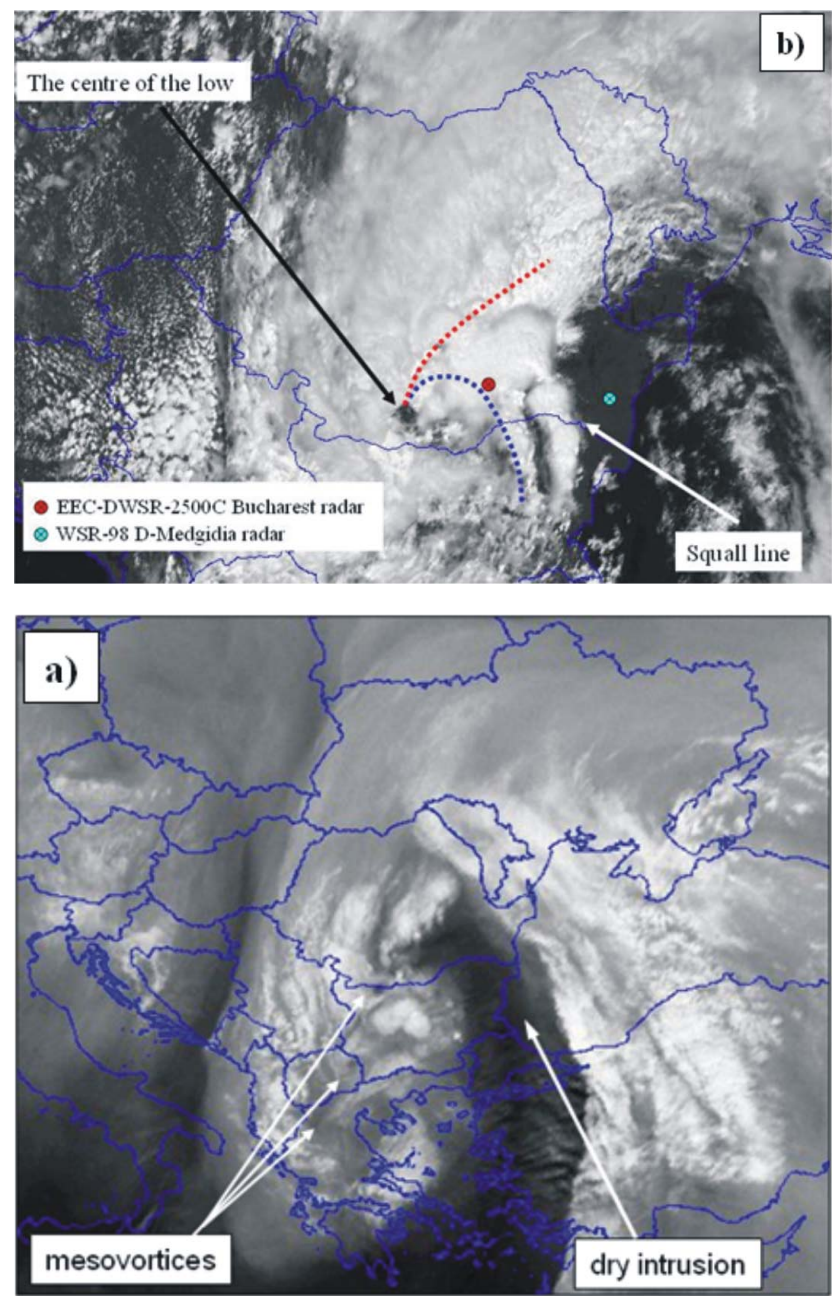

Fig. 11. (a) The MSG-2 water vapor image at 07:30 UTC 7 May 2005. Three mesovortices embedded within the ascending moist flow and dry intrusion are indicated. (b) The MSG-2 high resolution visible satellite image at 11:00 UTC 7 May 2005. The relative location of the EEC-DWSR-2500C Bucharest radar (with red circle) and WSR-98 D Medgidia radar (with blue circle). The squall line location and the centre of rotation of the low are indicated. The subjective surface frontal drawing is conventional.

ation and development. In this situation we can conclude that the basic ingredients for deep moist convection (Doswell, 1996), namely, lift, instability and strong moist advection, were present.

\subsection{Analysis of satellite images}

The MSG-2 water vapor image from 07:30 UTC (Fig. 11a) shows a dark zone extending from the Mediterranean Sea to the south of Romania associated with a dry intrusion that is well correlated with mid-tropospheric descending motion and a low tropopause. Maximum radiance contrast at the east of this dark zone is correlated with a jet axis (Santurette 
and Georgiev, 2005). Also detectable in this image and in the water vapor loop are three mesovortices embedded within the ascending moist flow. Because there is no dense cloud cover associated with them, the water vapor image shows a dry patch at the center of each mesovortex. The mesovortices formation was associated with a thermal perturbation observed at 500-hPa (Fig. 5b). These mesovortices also appear in the 850-hPa ALADIN model analysis at 06:00 UTC (Fig. 7a) as mesolows in the height field. This means that the dry intrusion observed in the water vapor image extends to midlow levels. The water vapor and infrared images also show a convective development over Romania and Bulgaria, and a cold dry flow that formed a tongue of upper-tropospheric descending air over the south of Romania. The moist part of the leading edge of the dry intrusion moves quickly along the cold front from upper and mid-levels, fans out near the centre of the low, and then the dry intrusion surges perpendicularly to the surface cold front (Browning, 1997).

The squall line and the center of rotation of the low were visible in the MSG-2 high resolution $(1 \mathrm{~km})$ visible channel at 11:00 UTC (Fig. 11b), corresponding to tornado observation time. In this image the squall line appears very clear, between a cloud-free area ahead and a cloud covered area behind.

\section{Evolution of the storm from radar images}

The first convective activity developed early in the day, in the south of Romania at about 05:00 UTC, as a small cluster of thunderstorms. The convective cells developed in the warm sector and moved from south to north with the mean wind in the hilly and mountain area. Three hours later this cluster evolved into three parallel linear multi-cell systems which were parallel to mean wind. Existence of a southeasterly low level jet contributed to the generation of new cells upstream of maturing convective cells. And all these cells passed over the same location for six hours. Large precipitation amounts accumulated in the Carpathian Mountains, causing flash floods in villages and small watersheds of this region. A second severe phenomenon was the damaging winds and tornadoes along the path of a bow echo.

While the multi-cell convective system was active in the hilly region at 09:00 UTC, a new convective linear system formed in the south of the country (not shown). It had a NW-SE orientation and moved rapidly to the north-east with a speed of about $70 \mathrm{~km} \mathrm{~h}^{-1}$. As, the convective line approached the location of the C-band radar (at Bucharest), the reflectivity diminished due to the radar scanning limitation. Just after the convective line passed from Bucharest it formed into a large squall line with a bow-shaped convective system at the northern end of the line (Fig. 12). The leading edge of the bow echo had a strong reflectivity gradient observed well with the S-band WSR-98 D radar from Medgidia (Fig. 12).
Between 11:00 UTC and 13:30 UTC, as this squall line crossed the south-eastern part of the country, its northern end conserved the bowed structures, high reflectivity values and high reflectivity gradients in front of the line. Potentially dry air associated with the descending rear inflow jet was evident in the reflectivity field as rear inflow notches (RIN) or areas of weaker reflectivity behind the bowing line (Fig. 12). As the squall line approached the WSR-98 D radar from Medgidia at 11:52 UTC, the gust front line, associated with the cooled descending air, was evident in the reflectivity field (Fig. 12b and c). The bow-echo became much larger in extent and its activity was focused on the thermal discontinuity line zone depicted in Fig. 10. The northern part of the squall line that coincides with the bow echo was oriented perpendicular to the mean wind; the southern part of the squall line was parallel with low-level southerly jet and was formed from scattered convective elements (Fig. 12). After 14:00 UTC, the squall line almost dissipated. The length of the squall line varied between 150 and $250 \mathrm{~km}$ and the length of the bow-echo varied between 50 and $100 \mathrm{~km}$.

A vertical cross section of reflectivity through the core of the bow echo, along the line AB as seen in Fig. 13a, depicted strong, upright convective cells at the leading edge. This indicates strong ascending flows through the convective cells and extending aloft within the anvil.

Because the distance between the Bucharest radar and the squall line system was only about $30 \mathrm{~km}$, the C-band radar was able to explore correctly the convective system structures. The radar Doppler velocity depicted cyclonically rotational structures (within the limitation of the C-band radar) associated with the left end of the bow echo at all radar elevations (white circle, Fig. 14). These cyclonically rotational structures were observed between 10:30 UTC and 11:10 UTC, when the tornado was reported in Movilita village. During this time, part of the rear inflow jet (RIJ) appeared to move cyclonically at the left end of the bow echo. This can be explained due to increased shear as the RIJ descended and approached the surface.

After the squall line passed from Movilita village, it propagated with the same velocity $\left(70 \mathrm{~km} \mathrm{~h}^{-1}\right)$ to the north-east, accompanied by a trailing region of stratiform precipitation (Fig. 12).

\section{Summary and conclusions}

On 7 May 2005, a squall line with an embedded bow echo formed over Southern Romania causing severe wind damage. Three small tornadoes were reported by witnesses, two of them being recorded by video camera. The site survey confirmed wind damage associated with these tornadoes, two of them were weak (F0) and the third was more intense being classified as F1 on the Fujita scale. The synoptic and mesoscale conditions associated with the 7 May 2005 

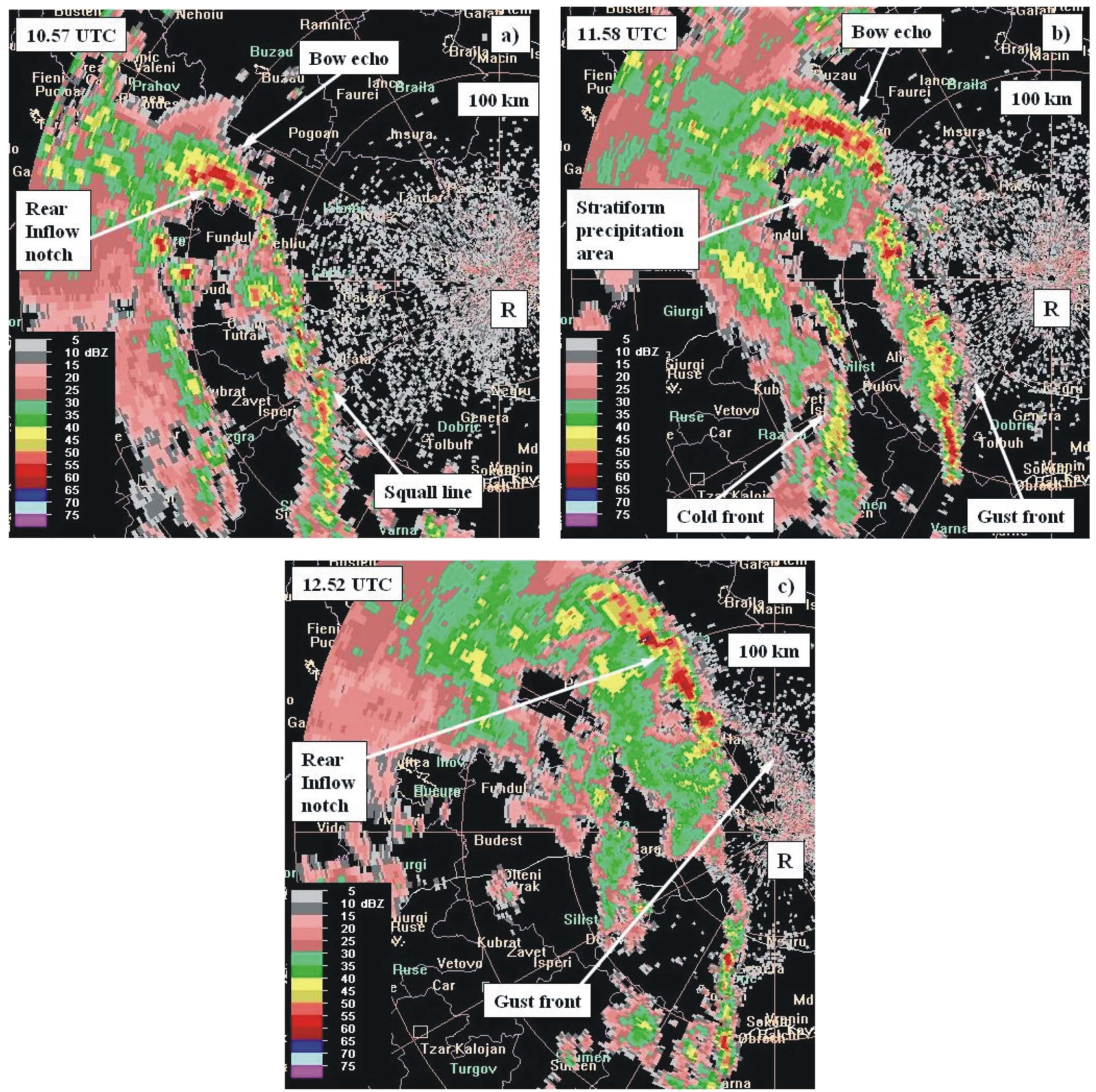

Fig. 12. Sequence of base reflectivity from the WSR-98 D Medgidia radar (depicted with R) at $0.5^{\circ} \mathrm{C}$ tilt at: (a) 10:57 UTC, (b) $11: 58$ UTC and (c) 12:52 UTC. Identified are the squall line, bow echo and rear inflow notch, trailing region of stratiform precipitation, gust front and cold front. The distance from the radar to the second circle is $100 \mathrm{~km}$. The area depicted is a zoom represented by the white rectangle number 2 from Fig. 2.

Southern Romania squall line with bow-echo is summarized by the composite chart valid for 11:00 UTC (Fig. 15).

- The squall line with an embedded bow echo formed along a surface thermal and moisture boundary line ahead of the surface cold front associated with a strong low pressure system.

- The squall line formed within the 925-hPa wet bulb po- tential temperature ridge as a southerly low level jet of $16 \mathrm{~m} \mathrm{~s}^{-1}$ at $850-\mathrm{hPa}$ was advecting a warm and moist air mass into Southern Romania.

- Ahead of the bow echo, the vertical profile of the wind showed a veering of the wind at low levels with generally constant wind direction at mid and upper levels.

- Behind the bow echo, the vertical profile of the wind 

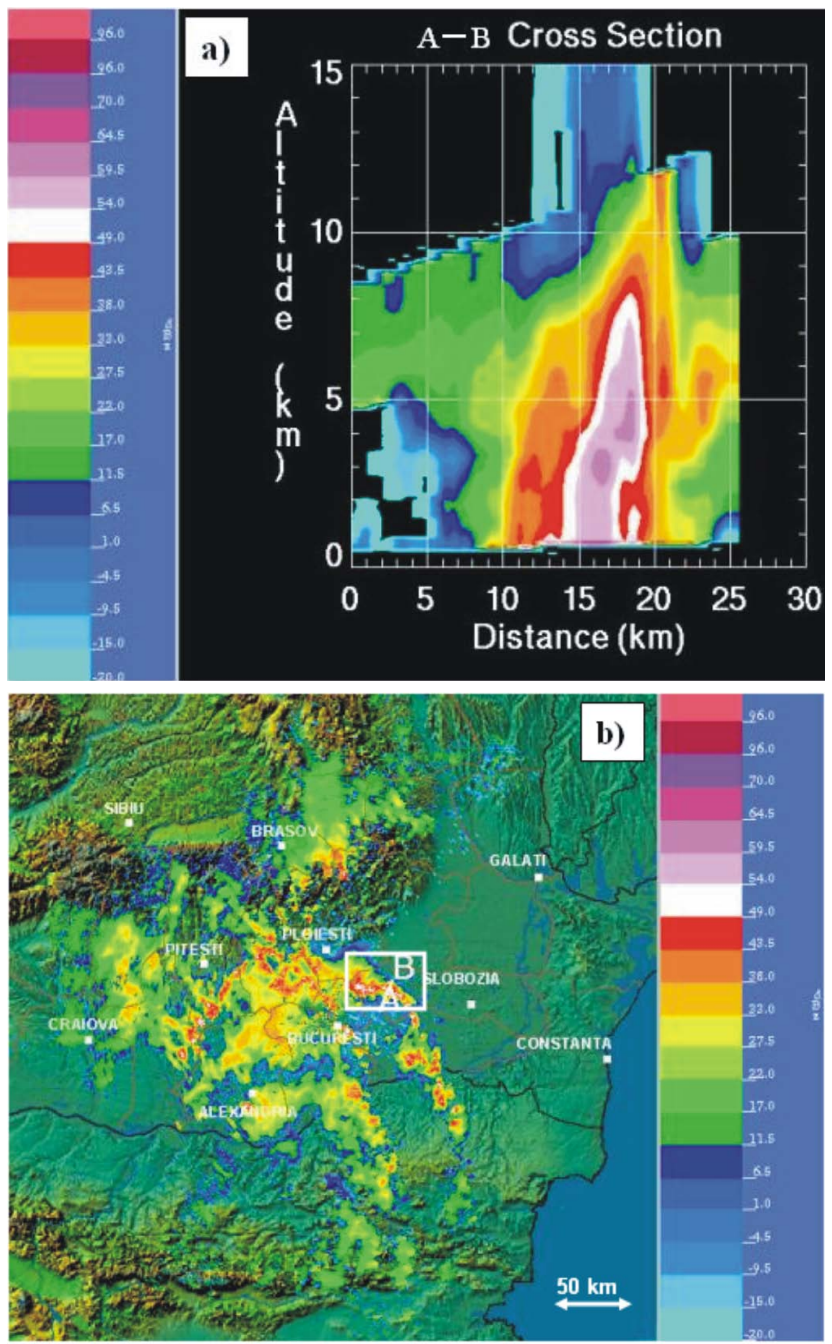

Fig. 13. (a) Vertical cross section through the middle of the echo (line AB) from (b) EEC-DWSR-2500C Bucharest radar reflectivity at $0.5^{\circ}$ tilt at 10:50 UTC 7 May 2005. The white rectangle represents the area depicted in Fig. 14.

indicates unidirectional (near south-westerly wind at all levels). The winds are stronger than those ahead of the bow echo, and the rear inflow jet of $16-18 \mathrm{~m} \mathrm{~s}^{-1}$ at 850 hPa was present.

- The upper levels winds were parallel with the low level wind both sides of the bow echo as the vertical profile indicated.

- The squall line traveled along a low-level thermal boundary oriented nearly parallel with the mean wind.

The vertical profiles of the wind obtained from the ALADIN model at 12:00 UTC, behind and ahead of the event (points A and B from Fig. 15) depicts strong vertical wind shear at low levels with unidirectional shear at medium and upper levels ahead of the event and unidirectional shear to the rear of the event.

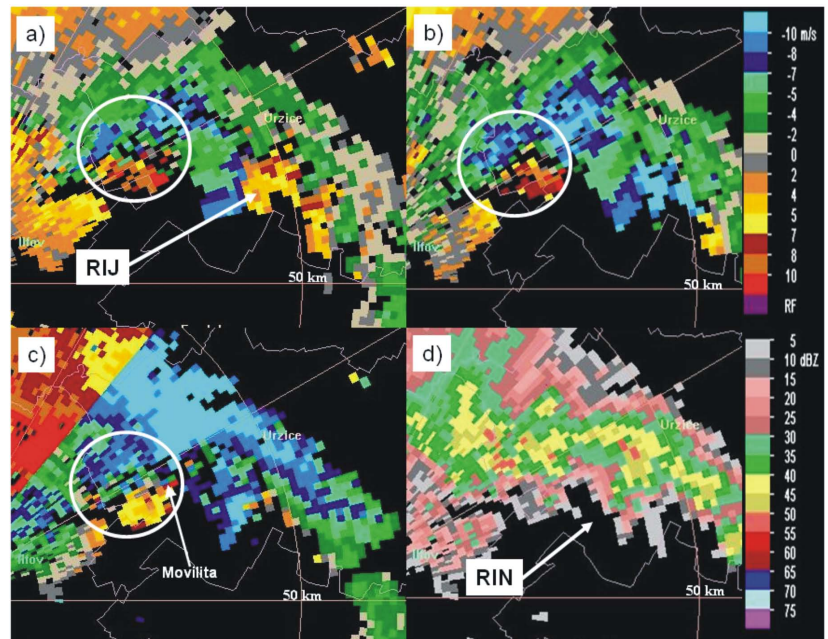

Fig. 14. The EEC-DWSR-2500C data from Bucharest radar. Doppler velocity data at (a) $2.4^{\circ}$ tilt with radar beam at $1500 \mathrm{~m}$ high, (b) $1.5^{\circ}$ tilt with radar beam at $900 \mathrm{~m}$ high, (c) $0.5^{\circ}$ tilt with radar beam at $400 \mathrm{~m}$ high and (d) reflectivity at $0.5^{\circ}$ tilt at 11:00 UTC 7 May 2005. Rear inflow jet (RIJ) and rear inflow notch (RIN) is indicated. The area depicted is a zoom represented by the white rectangle in Fig. 13b and also by the white rectangle number 3 from Fig. 2.

The synoptic and mesoscale conditions associated with the 7 May 2005 Southern Romania squall line with bow-echo appear to have similarities with those described by studies of "dynamic" derechoes (Johns and Hirt, 1987) (Fig. 1b). These similarities include: initiation of the squall line in the warm sector of a strong surface low associated with an upper level trough; development of the squall line ahead of a cold front and development of the tornado structures associated with a portion of the bow-echo (Johns et al., 1993). Other similarities with the "dynamic" pattern are the existence of stronger midlevel winds in the 7 May 2005 event and the presence of dry, potentially cold intrusions in the downdraft entrainment region. The differences includes the amount of potential instability over the genesis area, orientation of the limited bowing segment normal to the mean wind and the moving of the bow echo along the surface thermal boundary that are typically associated with "warm-season" derechoes (Johns and Hirt, 1987). Due to the Romanian topography with the Carpathian Mountains situated in the middle of the country, severe wind damage reports caused by convective storms cannot affect an area more than $400 \mathrm{~km}$ in length as the Johns and Hirt (1987) derecho definition requires. The squall lines observed in Romania have a major axis length between $100 \mathrm{~km}$ and $300 \mathrm{~km}$ (Stan-Sion, 2007).

The most classic synoptic pattern in North America involves north-westerly flow aloft, whereas in Romania, southerly upper flow is often associated with severe events.

The EEC-DWSR-2500C Bucharest radar and the WSR$98 \mathrm{D}$ Medgidia radar were important tools in the detection 


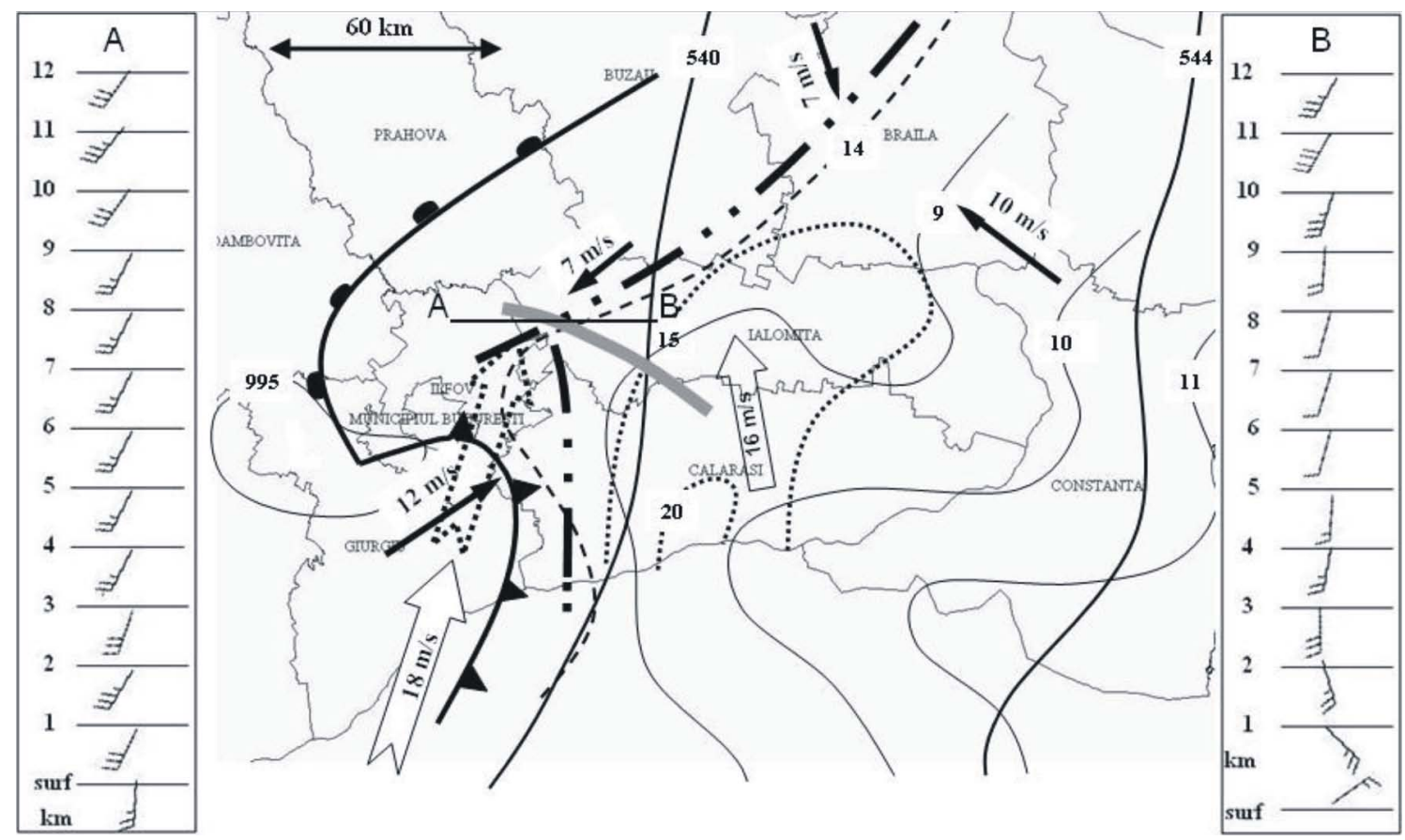

Fig. 15. Composite chart for 11:00 UTC 7 May 2005. Identified are 500-hPa heights in decameters (solid lines), surface front (conventional symbol), position of the surface low (depicted by L), 850-hPa temperature in degrees Celsius (thin line), $925 \mathrm{hPa}$ wet bulb potential temperature (dashed line with $14^{\circ}$ ), surface dewpoint temperature in degrees Celsius (squared dot lines), low level jet in front of the squall line (arrow with $16 \mathrm{~m} / \mathrm{s}$ and rear inflow jet (arrow with $18 \mathrm{~m} / \mathrm{s}$ and arrow with squared dots) that impinges in the rear part of the bow echo and $10 \mathrm{~m}$ wind from real observations (black arrows). The thermal and moist convergence lines are depicted with long dashed-dot lines. The vertical profiles of the wind from ALADIN model are depicted $30 \mathrm{~km}$ to the rear (A) and $30 \mathrm{~km}$ in front (B) of the bow echo. The bow echo location is depicted with a thick grey line.

of the radar signature associated with the 7 May 2005 bow echo. The identified bow echo patterns are summarized:

- A rear inflow notch was evident in the radar reflectivity image.

- A high reflectivity gradient was observed in front of the line.

- The rear inflow jet was evident in the Doppler radial velocity image at about $1500 \mathrm{~m}$ from the ground.

- The vertical cross-section of reflectivity through the core of the bow echo depicted strong, upright convective cells at the leading edge.

- The radar Doppler velocity depicted cyclonically rotational structures associated with the left end of the bowed echo.

The 7 May squall line had some features in common with the type 1 radar echo pattern introduced by Przybylinski (1995). It was characterized by a bow echo $100 \mathrm{~km}$ in length with an associated mesocirculation near the northern end. A strong low-level reflectivity gradient was observed along the leading edge of the bow and a rear inflow notch was present behind the leading line.
The cyclonically rotational structures were observed between 10:30 and 11:10 UTC, when a tornado was reported in Movilita village. Thus, the wind damage reported in Movilita village was due to the intensification of the rear inflow jet and due to tornado event. It was not possible to identify the radar structures which generated the Buftea and Ciobanu tornadoes, but it is likely that they were associated with mesovortices along the gust front.

At the time of this event, Romanian forecasters had a lot of experience in accurately forecasting the weather associated with Mediterranean Cyclones and in issuing warnings for the location of heavy rain. Upon the installation of the Doppler radar network, the Romanian forecaster was challenged to recognize environmental factors that favor supercell development. However, the environment that is particularly favorable for bow echo formation and its associated tornadoes were concepts totally unknown to our forecasters at the time of this event.

The Johns and Hirt $(1987,1993)$ studies offer a useful model for the recognition of an environment favoring bow echoes and consequently better short term forecasting. The identification of the bow echo pattern on the radar can contribute to improvements of the warnings decisions. The Romanian bow echo cases have many similarities with the 
cases observed in United States and Europe, although the mesoscale flows induced by the Carpathian Mountains and the Black Sea, create several differences. This study is the first step in creating an appropriate conceptual model for squall line and bow echo formation in Romania.

Acknowledgements. The authors are especially grateful to acknowledge D. Banciu and S. Tascu for their preparation of model data products and S. Stefan for her encouragement in the completion of this work. The authors also acknowledge the experts team that performed the damage survey. The authors would like to acknowledge the comments and suggestions of the anonymous reviewers that greatly improved the paper.

Edited by: A. Loukas

Reviewed by: three anonymous referees

\section{References}

Atkins, N. T., Arnott, J. M., Przybylinski, R. W., Wolf, R. A., and Ketcham, B. D.: Vortex structure and evolution within bow echoes. Part I: Single-Doppler and damage analysis of the 29 June 1998 derecho, Mon. Weather Rev., 132, 2224-2242, 2004.

Arnott, J. M. and Atkins, N. T.: Tornadogenesis within quasilinear convective systems. Part I: Radar and storm damage analysis of the 29 June 1998 derecho, Preprints, 21st Conf. on Severe Local Storms, San Antonio, TX, Amer. Meteor. Soc., 494-497, 2002.

Bell, A.: Radar Characteristics of Tropical-like Severe Storms in Romania, Conference on Radar in Meteorology and Hydrology (ERAD2008), Helsinki, Finland, ISSN: 978-951-697-676-4, 2008.

Browning, K. A., and Pardoe, C. W.: Structure of low-level jet streams ahead of mid-latitude cold fronts, Q. J. Roy. Meteor. Soc., 99, 619-638, 1973.

Browning, K. A., Ballard, S. P., and Davitt, C. S. A.: HighResolution Analysis of Frontal Fracture, Mon. Weather Rev., 125, 1212-1230, 1997.

Doswell III, C. A., Brooks, H. E., and Maddox, R. A.: Flash flood forecasting: An ingredients-based methodology, Weather Forecast., 11, 560-581, 1996.

Burgess, D. W. and Smull, B. F.: Doppler radar observations of a bow echo associated with a long-track severe windstorm, Preprints, 16th Conf. on Severe Local Storms, Kananaskis Park, AB, Canada, Amer. Meteor. Soc., 203-208, 1990.

Coniglio, M. C., Stensrud, D. J., and Richman, M. B.: An Observational Study of Derecho-Producing Convective Systems, Weather Forecast., 19, 320-337, 2004.

Evans, J. S. and Doswell III, C. A.: Examination of derecho environments using proximity soundings, Weather Forecast., 16, 329-342, 2001.

Forbes, G. S. and Wakimoto, R. M.: A concentrated outbreak of tornadoes, downbursts and microbursts, and implications regarding vortex classification, Mon. Weather Rev., 111, 220-236, 1983.

Fujita, T. T. and Byers, H. R.: Spearhead echo and downburst in the crash of an airliner, Mon. Weather Rev., 105, 129-146, 1977.

Fujita, T. T.: Manual of downburst identification for project Nimrod, Satellite and Mesometeorology Research Paper 156, Dept. of Geophysical Sciences, University of Chicago, [NTIS PB286048], 104 pp., 1978.
Fujita, T. T.: Tornadoes and downbursts in the context of generalized planetary scales, J. Atmos. Sci., 38, 1511-1534, 1981.

Fujita, T. T. and Wakimoto, R. M.: Five scales of airflow associated with a series of downbursts of 16 July 1980, Mon. Weather Rev., 109, 1438-1456, 1981.

Funk, T. W., Darmofal, K. E., Kirkpatrick, J. D., DeWald, V. L., Przybylinski, R. W., Schmocker, G. K., and Lin, Y.-J.: Storm reflectivity and mesocyclone evolution associated with the 15 April 1994 squall line over Kentucky and southern Indiana, Weather Forecast., 14, 976-993, 1999.

Gatzen, C.: A Derecho in Europe: Berlin, 10 July 2002, Weather Forecast., 19, 639-645, 2004.

Hinrichs, G.: Tornadoes and derechos, Amer. Meteor. J., 5, 306317, 341-349, 1888.

Jorgensen, D. P. and Smull, B. F.: Mesovortex circulations seen by airborne Doppler radar within a bow-echo mesoscale convective system, B. Am. Meteorol. Soc., 74, 2146-2157, 1993.

Johns, R. H. and Hirt, W. D.: Derechos: Widespread Convectively Induced Windstorms, Weather Forecast., 2, 32-49, 1987.

Johns, R. H. and Doswell III, C. A.: Severe local storms forecasting, Weather Forecast., 7, 588-612, 1992.

Johns, R. H.: Meteorological Conditions Associated with Bow Echo Development in Convective Storms, Weather Forecast., 8, 294-299, 1993.

Keyser, D. and Shapiro, M.: A Review of the Structure and Dynamics of Upper-Level Frontal Zones, Mon. Weather Rev., 114, 452-499, 1986.

Kotroni, V. and Lagouvardos, K.: Low-level jet streams associated with atmospheric cold fronts - seven case studies from the FRONTS 87 experiment, Geophys. Res. Lett., 20(13), 13711374, 1993.

Lemon, L. R., Stan-Sion, A., Soci, C., and Cordoneanu, E.: A strong, long-track, Romanian tornado, Atmos. Res., 67-68, 391416, 2003.

López, J. M. and Arús, J.: A Mediterranean derecho: Catalonia (Spain), 17th August 2003, Preprints, Third European Conf. on Severe Storms, León, Spain, CD-ROM, P53, 2004.

Pfost, R. L. and Gerard, A. E.: "Bookend vortex" - induced tornadoes along the Natchez Trace, Weather Forecast., 12, 572-580, 1997.

Przybylinski, R. W.: The Bow Echo: Observations, Numerical Simulations, and Severe Weather Detection Methods, Weather Forecast., 10, 203-218, 1995.

Przybylinski, R. W., Schmocker, G. K. and Lin, Y.-J.: A study of storm and vortex morphology during the intensifying stage of severe wind mesoscale convective systems, Preprints, 20th Conf. on Severe Local Storms, Orlando, FL, Amer. Meteor. Soc., 173176, 2000.

Punkka, A. J., Teittinen, J., and Johns, R. H.: Synoptic and Mesoscale Analysis of a High-Latitude Derecho-Severe Thunderstorm Outbreak in Finland on 5 July 2002, Weather Forecast., 21, 752-763, 2006.

Santurette, P. and Georgiev, C. G.: Weather Analysis and Forecasting Applying Satellite Water Vapor Imagery and Potential Vorticity Analysis, Ed. Elsevier Academic Press, 180 pp., 2005.

Schmid, W., Schiesser, H. H., Furger, M., and Jenni, M.: The Origin of Severe Winds in a Tornadic Bow-Echo Storm over Northern Switzerland, Mon. Weather Rev., 128, 192-207, 2000. 
Stan-Sion, A. and Antonescu, B.: Mesocyclones in Romania - characteristics and environments, 23rd Conf. on Severe Local Storms, San Louis (MO), USA, 5-10 November, 2006.

Stan-Sion, A., Stumpf, G., and Antonescu, B.: An exceptional tornado outbreak during 2005 in southeastern Romania, European Geosciences Union (EGU 2006) Vienna, Austria, 2-7 April, (ISSN: 1029-7006), 2006.

Stan-Sion, A., Oprea, C. I., and Antonescu, B.: Bow echo characteristics in Romania, 33rd Conference on Radar Meteorology, Cairns, Australia, 6-10 August, 2007.

Stan-Sion, A. and Antonescu, B.: Mesocyclones characteristics in Romania, 33rd Conference on Radar Meteorology, 6-10 August, Cairns, Queensland, Australia, 2007.
Wakimoto, R. M.: The West Bend, Wisconsin storm of 4 April 1981: A problem in operational meteorology, J. Appl. Meteorol., 22, 181-189, 1983.

Weisman, M. L.: The genesis of bow echoes: A rear-inflow induced meso-convective structure, NCAR cooperative thesis No. 125, 148 pp. (Available from the National Center for Atmospheric Research, P.O. Box 3000, Boulder, Colorado, 80307), 1990.

The European Centre for Medium Range Weather Forecasters (ECMWF): http://www.ecmwf.int/research/ifs/, access: 23 April 2009.

Aire Limitee Adaptation Dynamique Developpement InterNational (ALADIN): http://www.cnrm.meteo.fr/aladin/, access: 23 April 2009. 